\title{
In-vitro Effects of Chlorpyrifos and Monocrotophos on the Activity of Acetylcholinesterase (AChE) in Different Tissues of Apple Snail Pila globosa (Swainson, 1822)
}

\author{
S. Pal*, S. Maity**, S. Balachandran*† and S. Chaudhury* \\ *Department of Environmental Studies, Siksha-Bhavana, Visva-Bharati, Santiniketan-731235, West Bengal, India \\ **West Bengal Zoo Authority, Aranya Bhawan, Salt Lake City-700106, West Bengal, India \\ $\dagger$ Corresponding author: S. Balachandran; s.balachandran@visva-bharati.ac.in
}

Nat. Env. \& Poll. Tech.

Website: www.neptjournal.com

Received: 07-09-2020

Revised: $09-11-2020$

Accepted: 12-11-2020

Key Words:

Apple snail

Chlorpyrifos

Monocrotophos

AChE activity

Hepatopancreas

\begin{abstract}
The impact of two organophosphorus insecticides [Chlorpyrifos (CPF) and Monocrotophos (MCP)] on non-target wild natural gastropod, Pila globosa (apple snail) from the paddy fields was studied. The activity of acetylcholinesterase (AChE) was monitored on foot-muscle and hepatopancreas tissues of control and exposed snails. In the foot- muscle AChE inhibition progressed and reached $54.19 \%$ and $63.13 \%$ of the control, whereas, the AChE inhibition in the hepatopancreas reached $46.96 \%$ and $53.67 \%$ over control after 48 hours of exposure to $1.5 \mathrm{~mL} . \mathrm{L}^{-1}$ and $2.5 \mathrm{~mL} . \mathrm{L}^{-1} \mathrm{CPF}$ respectively. After 48 hours of MCP exposure at $1.5 \mathrm{~mL} . \mathrm{L}^{-1}$ and $2.5 \mathrm{~mL} . \mathrm{L}^{-1}$ separately, the AChE inhibition of foot muscle was $49.07 \%$ and $57.59 \%$ respectively while in hepatopancreas it was $44.65 \%$ and $48.84 \%$ respectively. Our results show more inhibition of AChE activities on the foot-muscle than hepatopancreas in a concentration and time-dependent manner with greater severity by CPF in comparison to MCP. AChE inhibition increased with the increasing exposure time.
\end{abstract}

\section{INTRODUCTION}

Today's agricultural work is unthinkable without the use of pesticides. These widely spread pesticides are used to control agricultural pests, but at the same time, they are highly toxic to non-target natural populations particularly in the aquatic environment. This necessitated the need to understand and evaluate the biological effects of xenobiotics on the aquatic ecosystem (Ullah et al. 2018). According to Sunanda et al. (2016), organophosphorus (OP) insecticides are increasingly used in agriculture as a substitute for organochlorine and carbamate insecticides because of their high efficiency and low persistence in the environment. Chlorpyrifos (CPF) and monocrotophos (MCP) are the commonly used OP insecticides that are often detected in the freshwater system (Narra et al. 2017). Unfortunately, organophosphorus pesticides due to their lack of target specificity can cause serious, long-lasting effects on aquatic non-prey species, especially invertebrates (Wang et al. 2018). Therefore, an appropriate monitoring strategy is needed to measure the environmental risks and to protect the non-target organism like invertebrate species from the effects of OP pesticides.

Although OP compounds can break down rapidly in the environment, non-target organisms may suffer from chronic effects, such as AChE inhibition (Nguyen et al. 2018) due to indiscriminate applications of these OPs in the paddy fields. OP compounds have several toxic properties but the most concern is AChE inhibition. OP interferes with the activity of the enzyme AChE, leading to prolonged muscle contraction (Bolton-Warberg et al. 2007). Moreover, the inhibition of $\mathrm{AChE}$ results in abnormal respiration, swimming, feeding due to loss of coordination, tremors, muscle spasms, convulsions, and even death (Tam et al. 2015, Ihsan et al. 2019). AChE activity is therefore widely used in biomonitoring studies as a biomarker of OP pesticide exposure (Khalil 2015). Freshwater molluscs display high sensitivity to aquatic pollutants, making them an ideal bio-indicator model in the field (Wang et al. 2018).

Molluscs are well-known for their capacities to accumulate different classes of chemicals in their tissues such as the head, kidney, foot muscle, and particularly the hepatopancreas (Regoli et al. 2006). But AChE activity has only been studied in a limited number of molluscan species exposed to xenobiotics and often using only one kind of tissue, which makes it difficult to compare the results obtained by different authors (Kopecka-Pilarczyk 2010).

Pesticide pollution in the agricultural fields is a matter of growing interest. Since the real toxicological impacts remain 
largely unexplored in field conditions, the main objective of the present study was to develop an integrated ecotoxicological approach with the apple snail $P$. globosa (Swainson) for monitoring toxicological effects caused by two extensively used organophosphate pesticides, chlorpyrifos (CPF) and monocrotophos (MCP).

P. globosa is a very common economically important gastropod found in paddy fields and ponds of West Bengal, India. Apple snails being herbivore and detritivore play a major role in numerous ecosystems. It is a prey to several predators such as reptiles, birds, and mammals thus, it can be the base point at the origin of the food web, transfer xenobiotics (Laskowski \& Hopkin 1996) to higher trophic levels leading to biomagnification.

Due to the paucity of information on the effects of CPF and MCP on AChE of P. globosa an attempt has been made to investigate the short-term effect of these two OP pesticides in the metabolically active tissues (hepatopancreas and foot muscle) of the said gastropod.

\section{MATERIALS AND METHODS}

\section{Experimental Design}

84 mature apple snail P. globosa, weighing $15 \pm 2 \mathrm{~g}$ were collected during monsoon from an untreated pond not having pollution history far away from the agricultural sites and subjected to experiments. 4 snails were considered as control and other 80 snails confined with nylon net was exposed in the separate paddy fields sprayed with the different concentrations of the two OP pesticides; chlorpyrifos (CPF) and monocrotophos (MCP) with the concentrations of 1.5 mL. $\mathrm{L}^{-1}$ water and $2.5 \mathrm{~mL} . \mathrm{L}^{-1}$ water for a period of 48 hours (exposure periods of 3, 6, 12, 24 and 48 hours). Finally, the experimental groups were as follows.

Group I-Control, snails unexposed to the pesticide; Group II-20 snails exposed to $1.5 \mathrm{ml} \mathrm{L}^{-1}$ of CPF for different time periods; Group III-20 snails exposed to $2.5 \mathrm{ml} . \mathrm{L}^{-1}$ of CPF for different time periods; Group IV-20 snails exposed to 1.5 $\mathrm{mL} . \mathrm{L}^{-1}$ of MCP for different time periods; Group $V-20$ snails exposed to $2.5 \mathrm{~mL} . \mathrm{L}^{-1}$ of MCP for different time periods.

For enzyme assay, four specimens from each exposed group were collected randomly per exposure duration $(3,6$, 12,24 , and 48 hours) and quickly transported to the laboratory in an icebox to avoid tissue degradation.

\section{Chemicals}

All chemicals used were of analytical grade purchased from Sigma Chemical Company (USA).

\section{AChE assay (EC 3.1.1.7)}

AChE activity of P. globosa was determined spectrophotometrically under laboratory conditions according to the method of Ellman et al. (1961) by measuring the rate of hydrolysis of the substrate. To improve the standard of analytical accuracy and precision of the enzyme assay, the present investigation focuses on the conditions under which it is measured. Considered parameters for the present quality assurance and quality control procedure are temperature, $\mathrm{pH}$, ionic strength, and concentrations of the reactants (substrate and enzyme) which influence the enzyme sensitivity in a reaction mixture. For each assay, four collected specimens from each concentration of CPF and MCP (one from each replicate) at an interval of 3, 6, 12, 24, 48 hours were sacrificed and pooled together before homogenization of the tissue sample. Foot muscle and hepatopancreas tissues were taken out immediately by breaking shells and $10 \%(\mathrm{w} / \mathrm{v})$ tissue homogenate were prepared separately in ice-cold 0.1 M phosphate buffer of $\mathrm{pH} 8.0$ standardized specifically for $P$. globosa AChE activity. Tissue homogenate was centrifuged at $10000 \mathrm{rpm}$ for $30 \mathrm{~min}$ at $4^{\circ} \mathrm{C}$ in a Remi CM-8 plus cooling centrifuge. A reaction cocktail of $3 \mathrm{ml}$ volume was prepared using $60 \mu \mathrm{l}$ clear supernatant (enzyme source), $0.1 \mathrm{M}$ of phosphate buffer ( $\mathrm{pH} 8.0$ ), $0.5 \mathrm{M}$ of dithiobisnitrobenzoic acid (DTNB), and $1.84 \mathrm{~mm}$ acetylthiocholine iodide standardized for the AChE activity of this species. The change in optical density at $412 \mathrm{~mm}$ was recorded on a Beckman DU 640 UV/ Vis spectrophotometer for a $3 \mathrm{~min}$ time scan under optimum temperature $\left(30^{\circ} \mathrm{C}\right)$ in a $10 \mathrm{~mm}$ path length cuvette. A freshly prepared thiocholine standard curve (Jash et al. 1982) was used to measure the specific activity of AChE and expressed as n.mole ${ }^{-1}$ thiocholine produced $\mathrm{min}^{-1} \mathrm{mg}^{-1}$ protein. The protein content of the tissue samples was estimated using the Bovine Serum Albumin standard curve following the method of Lowry et al. (1951). All assays were done in triplicate to avoid errors and pitfalls during enzyme assay.

\section{Statistical Analysis}

The AChE activities of $P$. globosa are tabulated as mean \pm standard error of three replicates (each comprising four snails). Test of significance was performed by one-way analysis of variance followed by Duncan's multiple range test $(\mathrm{P}<0.05)$ using the statistical SigmaStat 3.0 program.

\section{RESULTS AND DISCUSSION}

\section{AChE Activity}

The AChE activity in the foot muscle and hepatopancreas of P. globosa following separate applications of low $\left(1.5 \mathrm{~mL} . \mathrm{L}^{-1}\right.$ 
of water) and high (2.5 mL.L ${ }^{-1}$ of water) concentrations of chlorpyrifos (CPF) and monocrotophos (MCP) is given in Tables $1 \& 2$ respectively. Statistically significant differences were observed in the inhibition of AChE activity between the control and CPF and MCP exposed foot muscle and hepatopancreas tissues after application of both low (1.5 $\left.\mathrm{mL} . \mathrm{L}^{-1}\right)$ and high $\left(2.5 \mathrm{~mL} . \mathrm{L}^{-1}\right)$ concentrations.

The studies have revealed that in the foot muscle of $P$. globosa, AChE inhibition progressed and reached 54.19\% and $63.13 \%$ of the control after 48 hours of exposure to 1.5 $\mathrm{mL}$ and $2.5 \mathrm{~mL} . \mathrm{L}^{-1}$ chlorpyrifos respectively. Whereas the AChE inhibition in hepatopancreas reached $46.96 \%$ and $53.67 \%$ over control after 48 hours exposed to lower and higher concentrations of CPF respectively. In the case of 1.5 $\mathrm{mL}$ and $2.5 \mathrm{~mL} . \mathrm{L}^{-1}$ of MCP exposure, the AChE inhibition of foot muscle was $49.07 \%$ and $57.59 \%$ respectively, while in hepatopancreas it was $44.65 \%$ and $48.84 \%$ respectively at the end of the exposure period. From the above results, it was clear that both organs exhibited more than a $30 \%$ decrease in the $\mathrm{AChE}$ activity when exposed to OP which reflects an indication of the risk of overexposure (Aprea et al. 2002). Therefore, the results indicated that the apple snails in the rice fields exposed to OP may be stressed for long hours even after the spraying has stopped.

When OP pesticides enter into the body of the snails, they move to all parts of the body and block AChE which hydrolyses the neurotransmitter acetylcholine. In this study, the reduction of AChE activity is assumed to result from the direct action of $\mathrm{CPF}$ and $\mathrm{MCP}$ exposure on the active site of this enzyme (Blodgett 2006). As with other OP, CPF and MCP inhibit nervous system function by binding with AChE, the enzyme responsible for the hydrolysis of the neurotransmitter acetylcholine at the cholinergic synapses. Binding AChE with OP pesticides allows the accumulation of acetylcholine at the nerve junction which leads to overstimulation of nicotinic and muscarinic receptors, thus disrupting neurotransmission (Yu et al. 2008).

The present study exhibited that the CPF and MCP inhibited the AChE activity in a similar pattern in both foot muscle and hepatopancreas tissues. A similar trend of AChE activities in all tissues exposed to the OP is in accordance with the previous study of Yaqin \& Hansen (2010). Gangnaire et al. (2008) reported that the inhibition of AChE activities has been found in a similar pattern in different tissues of freshwater snails, Potamopyrgus antipodarum, and Valvate piscinalis.

\section{Dose and Time-Dependent Response in AChE Activity}

The results in Tables $1 \& 2$ clearly show that the AChE activities in the foot muscle and hepatopancreas of P. globosa were influenced by the concentrations and duration of the exposure to CPF and MCP. The maximum negative effect was seen among the snails exposed to the highest concentration and a maximum exposure period. A relevant decrease was observed in the AChE activity by 22.89 to $54.19 \%$ and 29.17 to $63.13 \%$ in the foot muscle and $20.86 \%$ to 46.96 $\%$ and 23.37 to $53.67 \%$ in the hepatopancreas following the exposure to lower and higher concentrations of CPF respectively at the interim from 3 to 48 hours. Similarly, the decreased AChE activity was seen 19.07 to $49.07 \%$ and 24.35 to $57.59 \%$ in the foot muscle and 15.10 to $44.65 \%$ and 20.08 to $48.84 \%$ in the hepatopancreas following the lower and higher concentrations of MCP respectively throughout the exposure period.

From the above result, it was confirmed that $P$. globosa exposed to both CPF and MCP exhibited greater inhibition of AChE activity in both organs during the long exposure time and at medium concentrations of these OP pesticides. Such concentration-time response has also been found for a variety of OP insecticides in the tissues of gastropod, Planorbarius corneus (Cacciatore et al. 2013)

OP insecticides are highly toxic to aquatic animals, even at low concentrations (Humphrey et al. 2004, Narra et al. 2011). The time gap between the spraying of pesticides and the elevated AChE inhibition levels in the case of apple snails was indicative of the time required for the apple snail to absorb the pesticides. It also emphasized the stress responses of the apple snail and how the snail failed to endure the elevated stress. The OP needs time to be activated into its oxon- metabolite by cytochrome P450 enzyme to become toxic and inhibit AChE activity (Barata et al. 2004, Narra et al. 2011). The reaction of OP pesticides with AChE is progressive in that the longer the inhibitor is in contact with the enzyme the greater the inhibition (Sturn et al. 2007). In P. globosa AChE activity gradually decreased when the exposure time was increased. This was because the OP reduced the power of muscle contraction of the snail resulting in losing the ability to close its operculum making it more susceptible to the toxicity of the OP pesticides for the prolonged period of exposure. The most severe sign of neurotoxicity was the abnormal protrusion of the head-foot region from the shell in freshwater gastropod Chilina gibbosa (Cossi et al. 2015). A positive correlation with chlorpyrifos concentrations and time of exposure associated with the degree of AChE inhibition of Lanistes carinatus was recorded in the successive durations of exposure (Khalil 2015). These findings were in accordance with the results of the present investigation, which indicated that different pesticides will have different affinities to the active site of the AChE and therefore different concentrations and exposure times have a direct relationship 
between the degree of inhibition of AChE and toxicity of the OP pesticides (Kristoff et al. 2006)

\section{Tissue-Specific Analyses of AChE}

The significant inhibition of AChE in the foot muscle of $P$. globosa was observed at 48 hours of exposure, which was a maximum of $54.19 \%$ and $63.13 \%$ over the control after respective low and high concentrations of $\mathrm{CPF}$ exposure compared to $49.07 \%$ and $57.59 \%$ over the control after exposure in low and high concentrations of MCP respectively (Tables 1 \& 2). But no significant difference in $\mathrm{AChE}$ inhibition was recorded throughout the exposure period in the hepatopancreas tissue between low and high concentrations of CPF and MCP exposure though at $48 \mathrm{hrs}$ of exposure a remarkable inhibition was observed which were $46.96 \%$ and $53.67 \%$ over the control for the respective low and high concentrations of CPF while $44.65 \%$ and $48.84 \%$ inhibition were noted after low and high concentrations of MCP exposure respectively (Tables $1 \& 2$ ).

The inhibitory AChE activity in both foot muscle and hepatopancreas AChE activities exhibited a similar pattern of inhibition but the degree of AChE inhibition was higher in foot muscle than hepatopancreas at all the time intervals in the CPF and MCP exposed snails. This is the reflection of the higher sensitivity of foot muscle than hepatopancreas as the foot muscle is the main direct interacting organ of the surrounding toxic medium (Mundhe \& Pandit 2014). Foot muscle tissues of the apple snails evidenced an extremely decreased activity in the levels of AChE in both concentrations of CPF and MCP. The changes in the hepatopancreas suggest that it was relatively less affected than the foot muscle tissue. OP compounds were most likely, acting as neurotoxic agents with greater potency on the foot muscle of the apple snail because the foot muscle is innervated by nerves from several ganglia which represent the main target organ for high AChE activity.

The AChE inhibition is fairly related to the tissue innervation level. Hence, it can be concluded that the highest AChE concentration the highest inhibition susceptibility (Ram et al. 2011) which may be the cause behind the higher reduction in AChE activity in foot muscle than hepatopancreas in $P$. globosa. The depleted sequence in terms of decrement in AChE activity levels was: foot muscle $>$ hepatopancreas. Such sequence of depletion was reported by Putkome et al. (2008) where higher AChE inhibition was exhibited in muscle than digestive gland (hepatopancreas) when the golden apple snail Pomacea canaliculata was exposed to organophosphates CPF and dichlorvos.

\section{Pesticide Specific Inhibition of AChE}

The CPF was found to be more effective against this snail followed by MCP. CPF produced a maximum of $63.13 \%$ and $53.67 \% \mathrm{AChE}$ inhibition over control in the foot muscle and hepatopancreas respectively whereas MCP produced a maximum of $57.59 \%$ and $48.84 \%$ AChE inhibition over control in foot muscle and hepatopancreas respectively, after 48 hours of exposure to a higher dose $\left(2.5 \mathrm{~mL} \mathrm{~L}^{-1}\right)$. From this result, it was obvious that the inhibition was however more pronounced in $\mathrm{CPF}$ exposed snails indicating that the toxic potential of $\mathrm{CPF}$ is greater than that of MCP because CPF has a relatively persistent nature compared to $\mathrm{MCP}$ (Palma et al. 2009). CPF is metabolically converted by oxidative desulfuration into chlorpyrifos - oxon (CPO). The insecticidal action of CPF stems from the inhibition of AChE by CPO, resulting in severe cholinergic toxicity (Crane et al. 2012). The effect was confirmed by the observation of Rao et al. (2005) where at all the time intervals the CPF treated termites (Odontotermes obesus) exhibited more AChE inhibition than those exposed to MCP. A study by Tripathi \& Pandey (2016) found that the gill of $P$. globosa was affected by CPF with greater severity in comparison to MCP.

\section{CONCLUSIONS}

The present study indicated that $\mathrm{CPF}$ and MCP cause considerable inhibition of the AChE activity of a freshwater snail $P$.

Table 1: Biochemical responses of Pila globosa exposed to chlorpyrifos in paddy fields $(n=4)$.

\begin{tabular}{|c|c|c|c|c|c|c|c|c|}
\hline \multirow{2}{*}{$\begin{array}{l}\text { Biochemical } \\
\text { measurements }\end{array}$} & \multirow[t]{2}{*}{ Tissue } & \multirow{2}{*}{$\begin{array}{l}\text { Concentrations } \\
\text { of chlorpyrifos } \\
20 \% \text { EC }\end{array}$} & \multicolumn{6}{|c|}{ Duration of exposure (hour) } \\
\hline & & & 0 (control) & 3 & 6 & 12 & 24 & 48 \\
\hline \multirow{2}{*}{$\begin{array}{l}\text { AChE activity } \\
\text { n.mol. } \mathrm{mg}^{-1} \\
\text { protein } \mathrm{min}^{-1}\end{array}$} & \multirow[t]{2}{*}{ Foot } & $\begin{array}{l}1.5 \mathrm{~mL} . \mathrm{L}^{-1} \\
\text { water }\end{array}$ & $\begin{array}{l}144.56 \pm \\
2.49(100)^{\mathrm{Aa}}\end{array}$ & $\begin{array}{l}111.42 \pm 2.61 \\
(77.11)^{\mathrm{Bb}}\end{array}$ & $\begin{array}{l}105.09 \pm 2.03 \\
(72.73)^{\mathrm{Bb}}\end{array}$ & $\begin{array}{l}89.18 \pm 3.42 \\
(61.72)^{\mathrm{Bc}}\end{array}$ & $\begin{array}{l}78.55 \pm 3.65 \\
(54.36)^{\mathrm{Bc}}\end{array}$ & $\begin{array}{l}66.19 \pm 2.98 \\
(45.81)^{\mathrm{Bd}}\end{array}$ \\
\hline & & $\begin{array}{l}2.5 \mathrm{~mL} . \mathrm{L}^{-1} \\
\text { water }\end{array}$ & $\begin{array}{l}144.56 \pm 2.49 \\
(100)\end{array}$ & $\begin{array}{l}102.34 \pm 1.36 \\
(70.83)^{\mathrm{Bb}}\end{array}$ & $\begin{array}{l}95.58 \pm 1.82 \\
(66.15)^{\mathrm{Bb}}\end{array}$ & $\begin{array}{l}82.49 \pm 2.73 \\
(57.09)^{\mathrm{Bc}}\end{array}$ & $\begin{array}{l}74.89 \pm 2.08 \\
(51.83)^{\mathrm{Bc}}\end{array}$ & $\begin{array}{l}53.26 \pm 1.67 \\
(36.87)^{\mathrm{Cd}}\end{array}$ \\
\hline \multirow{2}{*}{$\begin{array}{l}\text { AChE activity } \\
\text { n.mol. } \mathrm{mg}^{-1} \\
\text { protein } \mathrm{min}^{-1}\end{array}$} & \multirow[t]{2}{*}{ Hepatopancreas } & $\begin{array}{l}1.5 \mathrm{~mL} . \mathrm{L}^{-1} \\
\text { water }\end{array}$ & $\begin{array}{l}118.20 \pm \\
1.53(100)\end{array}$ & $\begin{array}{l}93.54 \pm 2.98 \\
(79.14)^{\mathrm{Bb}}\end{array}$ & $\begin{array}{l}87.71 \pm 3.11 \\
(74.21)^{\mathrm{Bb}}\end{array}$ & $\begin{array}{l}78.80 \pm 1.65 \\
(66.67)^{\mathrm{Bc}}\end{array}$ & $\begin{array}{l}73.44 \pm 2.82 \\
(62.14)^{\mathrm{Bc}}\end{array}$ & $\begin{array}{l}62.69 \pm 2.48 \\
(53.04)^{\mathrm{Bd}}\end{array}$ \\
\hline & & $\begin{array}{l}2.5 \mathrm{~mL} \cdot \mathrm{L}^{-1} \\
\text { water }\end{array}$ & $\begin{array}{l}118.20 \pm \\
1.53(100)^{\mathrm{Aa}}\end{array}$ & $\begin{array}{l}90.57 \pm 3.07 \\
(76.63)^{\mathrm{Bb}}\end{array}$ & $\begin{array}{l}85.43 \pm 2.19 \\
(72.28)^{\mathrm{Bb}}\end{array}$ & $\begin{array}{l}74.17 \pm 1.36 \\
(62.75)^{\mathrm{Bc}}\end{array}$ & $\begin{array}{l}65.17 \pm 3.01 \\
(55.81)^{\mathrm{Bc}}\end{array}$ & $\begin{array}{l}54.76 \pm 2.39 \\
(46.33)^{\mathrm{Bd}}\end{array}$ \\
\hline
\end{tabular}


Table 2: Biochemical responses of Pila globosa exposed to monocrotophos in paddy fields $(\mathrm{n}=4)$.

\begin{tabular}{|c|c|c|c|c|c|c|c|c|}
\hline \multirow{2}{*}{$\begin{array}{l}\text { Biochemical meas- } \\
\text { urements }\end{array}$} & \multirow[t]{2}{*}{ Tissue } & \multirow{2}{*}{$\begin{array}{l}\text { Concentrations of } \\
\text { monocrotophos } \\
36 \% \text { SL }\end{array}$} & \multicolumn{6}{|c|}{ Duration of exposure (hour) } \\
\hline & & & 0 (control) & 3 & 6 & 12 & 24 & 48 \\
\hline \multirow{2}{*}{$\begin{array}{l}\text { AChE activity } \\
\text { n.mol.mg }{ }^{-1} \text { protein } \\
\min ^{-1}\end{array}$} & \multirow[t]{2}{*}{ Foot } & 1.5 mL.L ${ }^{-1}$ water & $\begin{array}{l}144.56 \pm \\
2.49(100)^{\text {Aa }}\end{array}$ & $\begin{array}{l}116.94 \pm 1.41 \\
(80.93)^{\mathrm{Bb}}\end{array}$ & $\begin{array}{l}108.49 \pm 3.56 \\
(75.05)^{\mathrm{Bb}}\end{array}$ & $\begin{array}{l}99.31 \pm 3.05 \\
(68.73)^{\mathrm{Bc}}\end{array}$ & $\begin{array}{l}89.15 \pm 3.72 \\
(61.69)^{\mathrm{Bc}}\end{array}$ & $\begin{array}{l}73.59 \pm 3.94 \\
(50.93)^{\mathrm{Bd}}\end{array}$ \\
\hline & & $2.5 \mathrm{~mL} . \mathrm{L}^{-1}$ water & $\begin{array}{l}144.56 \pm \\
2.49(100)\end{array}$ & $\begin{array}{l}109.31 \pm 2.04 \\
(75.65)^{\mathrm{Bb}}\end{array}$ & $\begin{array}{l}102.64 \pm 2.96 \\
(71.28)^{\mathrm{Bb}}\end{array}$ & $\begin{array}{l}90.94 \pm 4.76 \\
(62.94)^{\mathrm{Bc}}\end{array}$ & $\begin{array}{l}82.61 \pm 1.56 \\
(57.17)^{\mathrm{Bc}}\end{array}$ & $\begin{array}{l}61.28 \pm 2.10 \\
(42.41)^{\mathrm{Cd}}\end{array}$ \\
\hline \multirow{2}{*}{$\begin{array}{l}\text { AChE activity } \\
\text { n.mol.mg }{ }^{-1} \text { protein } \\
\text { min }^{-1}\end{array}$} & \multirow{2}{*}{ 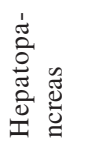 } & $1.5 \mathrm{~mL} . \mathrm{L}^{-1}$ water & $\begin{array}{l}118.20 \pm \\
1.53(100)^{\mathrm{Aa}}\end{array}$ & $\begin{array}{l}100.35 \pm 2.39 \\
(84.90)^{\mathrm{Bb}}\end{array}$ & $\begin{array}{l}92.49 \pm 3.01 \\
(78.21)^{\mathrm{Bb}}\end{array}$ & $\begin{array}{l}84.93 \pm 2.92 \\
(71.86)^{\mathrm{Bc}}\end{array}$ & $\begin{array}{l}80.74 \pm 1.85 \\
(68.31)^{\mathrm{Bc}}\end{array}$ & $\begin{array}{l}65.42 \pm 2.57 \\
(55.35)^{\mathrm{Bd}}\end{array}$ \\
\hline & & 2.5 mL.L ${ }^{-1}$ water & $\begin{array}{l}118.20 \pm \\
1.53(100)^{\mathrm{Aa}}\end{array}$ & $\begin{array}{l}94.46 \pm 3.90 \\
(79.92)^{\mathrm{Bb}}\end{array}$ & $\begin{array}{l}88.67 \pm 2.49 \\
(75.02)^{\mathrm{Bb}}\end{array}$ & $\begin{array}{l}81.16 \pm 3.05 \\
(68.67)^{\mathrm{Bc}}\end{array}$ & $\begin{array}{l}76.65 \pm 1.15 \\
(64.85)^{\mathrm{Bc}}\end{array}$ & $\begin{array}{l}60.45 \pm 3.11 \\
(51.16)^{\mathrm{Bd}}\end{array}$ \\
\hline
\end{tabular}

Results are exposed as mean \pm standard error. AChE, acetylcholinesterase. All values indicate mean \pm SE of three replicates, each comprising four snails. Significance was tested statistically by one-way analysis of variance (ANOVA) and Duncan's multiple range tests $(\mathrm{P}<0.05)$ within the same concentration among different exposure duration as well as within the same exposure duration between different concentrations of chlorpyrifos and monocrotophos. Values with the same superscript smaller case letters in a row are not significantly different from each other. Values with the same superscript capital letters in a column are not significantly different from each other. Values in parenthesis indicate percent enzyme activity with control taken as $100 \%$.

globosa under field conditions. Our findings show that $\mathrm{AChE}$ activity in $P$. globosa was a very useful bioindicator species showing a strong sensitivity and increasing the possibility to indirectly detect the presence of OP compounds in the aquatic system. The fluctuating levels of AChE in P. globosa can be used for biomonitoring the non-target aquatic species exposed to xenobiotics.

\section{REFERENCES}

Aprea, C., Colosio, C., Mammone, T., Minoia, C. and Maroni, M. 2002. Biological monitoring of pesticide exposure. Review of analytical methods. J. Chromatogr B, 769: 191-219.

Barata, C., Solayan, A. and Porte, C. 2004. Role of cholinesterases in assessing the toxicity of OP (Chlorpyrifos, malathion) and carbamate (carbofuran) pesticides to Daphnia magna. Aquatic Toxicol., 66: 125-139.

Blodgett, D. J. 2006. Organophosphate and Carbamate Insecticide. In: Peterson, M.E. and Talcott, P. A. (eds.) Small Animal Toxicology. Elsevier.

Bolton-Warberg, M., Coen, L. D. and Weinstein, J.E. 2007. Acute toxicity and acetylcholinesterase inhibition in grass shrimp (Palaemonetes pugio) and oysters (Crassostrea virginica) exposed to the organophosphate Dichlorvos: Laboratory and field studies. Arch. Environ. Contam. Toxicol, 52: 207-216.

Cacciatore, L.C., Guerrero, N.V. and Cochon, A.C. 2013. Cholinesterase and carboxylesterase inhibition in Planorbarius corneus exposed to a binary mixture of azinphos-methyl and chlorpyrifos. Aquat. Toxicol., 128-129: 124-134.

Cossi, P.F., Beverly, B., Carlos, L. and Kristoff, G. 2015. Recovery study of cholinesterase and neurotoxic signs in the non -target freshwater invertebrate Chilina gibbosa after acute exposure to an environmental concentration of azinphos-methyl. Aquat. Toxicol., 167: 248-56.

Crane, A.L., Klein, K., Zanger, U.M. and Olson, J.R. 2012. Effect of CYP2B6*6 and CYP2C19*2 genotype on chlorpyrifos metabolism. Toxicology, 293: 115-122.

Ellman, G.L., Courtney, K.D., Andres, V. and Featherstone, R.M. 1961. A new and rapid colorimetric determination of acetylchololinesterase activity. Biochem. Pharm., 7: 88-95.

Gangnaire, B., Geffard, O., Benoit, X., Margoum, C. and Garrie, J. 2008. Cholinesterase activities as potential biomarkers: Characterization in two freshwater snails, Potamopyrgu santipodarum and Valvata piscinalis. Chemosphere, 71: 553-560.
Humphrey, C.A., Klump, D.W. and Raethke, N. 2004. Pomancentrus amboinensis as a bioindicator organism for the Great Barrier Reef: Responses to chlorpyrifos. Bull. Environ. Contam. Toxicol., 72: 888-895.

Ihsan, T., Edwin, T. and Yanti, R.D. 2019. The effect of sublethal exposure of chlorpyrifos to Nile Tilapia (Oreochromis niloticus): case study of Twin Lakes of West Sumatra, Indonesia. Nat. Env. Poll. Tech., 18(4): 1399-1403.

Jash, N.B., Chatterjee, S. and Bhattacharya, S. 1982. Role of acetylcholine in the recovery of brain acetylcholinesterase in Channa punctatus (Bloch) exposed to furadan. Comp. Physiol. Ecol., 7: 56-58.

Khalil, A.M. 2015. Toxicological effects and oxidative stress responses in freshwater snail, Lanistescarinatus, following exposure to chlorpyrifos. Ecotox. Environ. Safety, 116: 137-42.

Kopecka-Pilarczyk, J. 2010. In vitro effects of pesticides and metals on the activity of acetylcholinesterase (AChE) from different tissues of the blue mussel, Mytilus trossulus L. Journal of Environmental Science and Health, Part B, 45: 46-52.

Kristoff, G., Guerroro, N.Y., de D'Angelo, A.M.P. and Cochon, A.C. 2006. Inhibition of cholinesterase activity by azinphos-methyl in two freshwater invertebrates Biomphalaria glabrata and Lumbriculus variegatics. Toxicology, 222: 185-194.

Laskowski, R. and Hopkin, S.P. 1996. Accumulation of $\mathrm{Zn}, \mathrm{Cu}, \mathrm{Pb}$, and $\mathrm{Cd}$ in the garden snail (Helix aspersa): Implications for predators. Environ. Pollut., 91: 289-297.

Lowry, O.H., Rosenbrough, N.J., Farr, A.L. and Randall, J. 1951. Protein measurement with the folin-phenol reagent. J. Biol. Chem., 193: 265-275.

Mundhe, A.Y. and Pandit, V.S. 2014. Assessment of toxicity of monocrotophos in freshwater bivalve Lamellidens marginalis, using different markers. Toxicol. Int., 21(1): 51-56.

Narra, M.D., Ghousia, B., Rajendar, K. and Rao, J.V. 2011. The toxic impact of two organophosphate insecticides on biochemical parameters of a food fish and assessment of recovery response. Toxicology and Industrial Health. DOI: 0748233711 412423: 1-10.

Narra, M.R., Rajender K, Reddy, R.R., Murty, U.S. and Begum, G. 2017. Insecticides induced stress response and recuperation in fish: Biomarkers in blood and tissues related to oxidative damage. Chemosphere, 168: 350-357.

Nguyen, T., Håkan, B. and Nguyen, V.C. 2018. Evaluation of the joint toxicity of chlorpyrifos ethyl and fenobucarb on climbing perch (Anabas testudineus) from rice fields in the Mekong Delta, Vietnam. Environ. Sci. Pollu. Res., 25(14): 13226-13234.

Palma, P., Palma, V.L., Fernandez, R.M., Bohn, A., Soares, A.M.V.M. and Barbosa, I.R. 2009. Embryo-toxic effects of environmental concen- 
trations of chlorpyrifos in the crustacean Daphnia manga. Ecotoxicol. Environ. Saf ., 72: 1714-1718.

Putkome, S., Cheevarporn, V. and Helander, H.F. 2008. Inhibition of acetylcholiesterase activity in the golden apple snail ( $P$. canaliculata) exposed to chlorpyrifos, dichlorvos, and carbaryl insecticides. Environ. Asia, 2: 15-20.

Ram, S.B.H., Devi, C.U., Susma, C., Jasti, V.R., Kumar, T.M.V. and Thirumurugan, G. 2011. Effect of polytrin C (combination pesticide) on the acetylcholiesterase inhibition in plasma and brain of Wistar rats. Am. J. Biochem. Mol. Biol., 1: 101-105.

Rao, V.J., Parvathi, K., Kavitha, P., Jakka, N. M., Pallela, R. 2005. Effect of chlorpyrifos and monocrotophos on locomotor behavior and acetylcholiesterase activity of subterranean termites. Pest Manag. Sci., 61: 417-421.

Regoli, F., Gorbi, S., Fattorini, D., Tedesco, S., Notti, A., Machella, N., Bocchetti, R., Benedetti, M. and Piva, F. 2006. Use of the land snail Helix aspersa as sentinel organism for monitoring ecotoxicological effects of urban pollution. Environ. Health Perspect., 114: 63-69.

Sturn, A., Radau, T.S., Hahn, T. and Schulz, R. 2007. Inhibition of rainbow trout acetylcholinesterase by aqueous and suspended particle-associated OP insecticides. Chemosphere, 68 (4): 605-612.

Sunanda, M., Rao, C. S. J., Neelima, K., Rao, G. and Simhachalam, G. 2016. Int. J. Pharm. Sci.: Rev. Res., 59: 299-305.
Tam, N. T., Berg, H., Tuyen, P. T. B. and Cong, N. V. 2015. Effect of chlorpyrifos ethyl on acetylcholinesterase activity in climbing perch (Anabas testudineus, Bloch, 1972). Arch. Environ. Contam. Toxicol., 69: 515-524.

Tripathi, N. and Pandey, R. 2016. Histochemical study of Pila globosa gill when exposed to a sublethal dose of monocrotophos and chlorpyrifos. Bioglobia, 3(2): 73-78.

Ullah, S., Li, Z., Hasan, Z., Khan, S. U. and Fahad, S. 2018. Malathion-induced oxidative stress leads to histopathological and biochemical toxicity in the liver of Labeorohita at acute concentration. Ecotoxicol. Environ. Saf., 161: 270-280.

Wang, Q., Hong, X., Chen, H., Yuan, L. and Zha, J. 2018. The neuropeptides of Asian freshwater clam (Corbicula fluminea) as new molecular biomarker basing on the responses of organophosphate chemicals exposure. Ecotoxicol. Environ. Saf., 160: 52-59.

Yaqin, K. and Hansen, P.D. 2010. The use of cholinergic biomarker, cholinesterase activity of blue mussel Mytilus edulis to detect the effect of organophosphorus pesticides. Afr, J. Biochem. Res., 4: 265-272.

Yu, F., Wang, Z., Ju, B., Wang, Y., Wang, J. and Bai, D. 2008. Apoptotic effects of organophosphorus insecticide chlorpyrifos on mouse retina in vivo via oxidative stress and protection of combination of vitamins C and E. Exp. Toxicol. Pathol., 59: 415-423. 